\title{
DDMC-p53 gene therapy with or without cisplatin and microwave ablation
}

This article was published in the following Dove Press journal:

OncoTargets and Therapy

20 May 2015

Number of times this article has been viewed

\author{
Wolfgang Hohenforst- \\ Schmidt ${ }^{1}$ \\ Paul Zarogoulidis ${ }^{2}$ \\ Joshua Stopek ${ }^{3}$ \\ Thomas Vogl ${ }^{4}$ \\ Frank Hübner' \\ J Francis Turner 5,6 \\ Robert Browning ${ }^{7}$ \\ Konstantinos Zarogoulidis ${ }^{2}$ \\ Antonis Drevelegas ${ }^{8}$ \\ Konstantinos Drevelegas ${ }^{8}$ \\ Kaid Darwiche? \\ Lutz Freitag9 \\ Harald Rittger ${ }^{10}$ \\ 'Il Medical Clinic, Coburg Hospital, \\ University of Wuerzburg, Coburg, Germany; \\ 2Pulmonary Department-Oncology \\ Unit, G Papanikolaou General Hospital, \\ Aristotle University of Thessaloniki, \\ Thessaloniki, Greece; ${ }^{3}$ Covidien, Jersey City, \\ NJ, USA; ${ }^{4}$ Department of Diagnostic and \\ Interventional Radiology, Goethe University \\ of Frankfurt, Frankfurt, Germany; ${ }^{5}$ Division \\ of Interventional Pulmonology, ${ }^{6}$ Medical \\ Oncology, Cancer Treatment Centers of \\ America, Western Regional Medical Center, \\ Goodyear, AZ, 'Pulmonary and Critical \\ Care Medicine, Interventional Pulmonology, \\ National Naval Medical Center, Walter \\ Reed Army Medical Center, Bethesda, MD, \\ USA; ${ }^{8}$ Radiology Department, Interbalkan \\ European Medical Center, Thessaloniki, \\ Greece; ${ }^{9}$ Department of interventional \\ Pneumology, Ruhrlandklinik, University \\ Hospital Essen, University of Essen- \\ Duisburg, Essen, Germany; ${ }^{10}$ Medical \\ Clinic I, 'Fuerth Hospital, University of \\ Erlangen, Erlangen, Germany
}

Correspondence: Paul Zarogoulidis Pulmonary Department-Oncology Unit, G Papanikolaou General Hospital, Aristotle University of Thessaloniki,

Thessaloniki, Greece

Fax +30231099 2424

Email pzarog@hotmail.com
Abstract: Lung cancer remains the leading cause of death in cancer patients. Severe treatment side effects and late stage of disease at diagnosis continue to be an issue. We investigated whether local treatment using 2-diethylaminoethyl-dextran methyl methacrylate copolymer with p53 (DDMC-p53) with or without cisplatin and/or microwave ablation enhances disease control in BALBC mice. We used a Lewis lung carcinoma cell line to inoculate 140 BALBC mice, which were divided into the following seven groups; control, cisplatin, microwave ablation, DDMCp53, DDMC-p53 plus cisplatin, DDMC-p53 plus microwave, and DDMC-p53 plus cisplatin plus microwave. Microwave ablation energy was administered at $20 \mathrm{~W}$ for 10 minutes. Cisplatin was administered as $1 \mathrm{~mL} / \mathrm{mg}$ and the DDMC-p53 complex delivered was $0.5 \mathrm{~mL}$. Increased toxicity was observed in the group receiving DDMC-p53 plus cisplatin plus microwave followed by the group receiving DDMC-p53 plus cisplatin. Infection after repeated treatment administration was a major issue. We conclude that a combination of gene therapy using DDMC-p53 with or without cisplatin and microwave is an alternative method for local disease control. However, more experiments are required in a larger model to identify the appropriate dosage profile.

Keywords: DDMC, p53, carboplatin, microwave, non-small cell lung cancer

\section{Introduction}

Lung cancer is the leading cause of cancer death, and has an increasing incidence. ${ }^{1,2}$ Currently, intravenous chemotherapy is considered effective and, in the case of adenocarcinoma, targeted treatment is administered..$^{3-12}$ Lung cancer is rarely diagnosed in its early stages because of lack of symptoms. The survival rate after surgery is based on stage at the time of diagnosis, particularly if there is lymph node involvement. ${ }^{5,12-15}$ Moreover, current intravenous treatment has severe side effects, which in many situations increase the cost to the health care system because of additional days of hospitalization. ${ }^{16-19}$ Therefore, novel local treatments are required in order to control the disease with less side effects. Several local modalities have been administered, either in the form of aerosol, gene therapy, intratumoral therapy, or ablation. ${ }^{20-28}$ However, there are safety concerns with several of the novel therapies, and the benefit of less systemic side effects is very important for patients. ${ }^{11,28-30}$ Each local treatment modality has come with its own advantages and disadvantages. In the case of aerosol chemotherapy or aerosol gene therapy, the tumor had to be less than $5 \mathrm{~cm}$ in diameter, otherwise administration would not be effective., , $27,31,32^{\text {Regarding intratumoral }}$ chemotherapy, a technical method had to be applied in order to reach the tumor and efficiently deliver the drug either through multiple needle punctures or by an endobronchial approach. ${ }^{11}$ In both cases, a major obstacle was encountered, ie, efficient drug diffusion. Passive and active transport are the two major methods via which a drug diffuses within tissue. ${ }^{33}$ Passive transport depends on the physical ability of each

submit your manuscript | www.dovepress.com 
substance to penetrate the tissue and diffuse appropriately, whereas active transport is a targeted approach based on antibodies that are used for penetration of specific tissue. Cancer tissue is not homogeneous, and in some situations an abscess is observed within a mass. Neoangiogenesis is another problem, and causes hemorrhage in many tumors, so caution is needed during administration. Local therapy, in the form of ablation, radiofrequency, or microwave, can be used in many cases of lung cancer.

The major obstacle with regard to local ablation remains tumor size. Tumors larger than $5 \mathrm{~cm}$ in diameter are difficult to handle with this type of treatment. ${ }^{34,35}$ The thermal effect depends on the extracellular matrix of the tumor, and the suggestion has been made to modify the matrix in order for the tumor tissue to be able to absorb more thermal energy by administering, eg, liposomal agents prior to thermal ablation or simultaneously. ${ }^{36}$ Nanocarriers have been investigated and found to show the enhanced permeability and retention effect. Drugs with nanocarriers have increased local deposition and diffusion. ${ }^{37,38}$ The enhanced permeability and retention effect can be controlled by heat shock protein 32 and carbon monoxide. ${ }^{39}$ Further, addition of polyethylene glycol has been observed to improve the enhanced permeability and retention effect, allowing sustained release of the drug since it cannot be recognized by macrophages. ${ }^{40}$ In a previous study using BALBC mice, we investigated whether simultaneous administration of lipiodol with cisplatin and/ or microwave energy would enhance the thermal effect and increase apoptosis. ${ }^{41}$ However, it was observed that lipiodol in its current form does not diffuse homogeneously, so the thermal effect is not enhanced. Further, when lipiodol was administered with cisplatin and microwave energy, there was increased toxicity. In this study, we investigated the novel non-viral vector, 2-diethylaminoethyl-dextran methyl methacrylate copolymer with p53 (DDMC-p53) with or without simultaneous administration of cisplatin and/or microwave ablation. Here we present data for diffusion of this gene therapy complex within the tumor tissue and its efficiency according to treatment group.

\section{Animals and methods Mice}

One hundred and forty BALBC mice aged 7-8 weeks were purchased from the experimental laboratory at Theiageneio Anticancer Hospital and divided into seven groups. Our institution has authorization for production and experimentation on mice (EL 25 BIO 011, EL 25 BIO 013). The mice were isolated (one mouse per cage) in a temperature-controlled room on a 12-hour light-dark cycle and were allowed free access to food and water. A Lewis lung carcinoma (CRL-1642 ${ }^{\mathrm{TM}}$ ) cell line was obtained from the American Type Culture Collection (Manassas, VA, USA). The cells were routinely cultured in $25 \mathrm{~cm}^{2}$ tissue culture flasks containing Roswell Park Memorial Institute (American Type Culture Collection, 30-2002) supplemented with 10\% fetal bovine serum (Biochrom, Darmstadt, Germany) according to the supplier's instructions. The cell line was incubated at $37^{\circ} \mathrm{C}$ in $5 \% \mathrm{CO}_{2}$. The cell doubling time was 21 hours. $^{22,42-46}$ At confluence, the cells were harvested with $0.25 \%$ trypsin and then resuspended at $1.5 \times 10^{6}$ cells in $0.15 \mathrm{~mL}$ of phosphate-buffered saline (Biochrom) that was injected into the mice. The suspension was inoculated subcutaneously (using a 27 -gauge needle, $1.5 \times 10^{6}$ cells) into the back of each mouse (Figure 1). The tumor volume was measured once weekly using bidimensional diameters (by caliper) with the equation $\mathrm{V}=1 / 2 a b^{2}$, where $a$ represents the length and $b$ represents the width $\left(\mathrm{mm}^{3}\right)$. The tumor was grown on the back of each mouse. When an approximate tumor volume of $100 \mathrm{~mm}^{3}$ was reached, the animals were randomly divided into the following seven groups, with 20 mice in each group: control, cisplatin, microwave energy, DDMC-p53, DDMC-p53 plus cisplatin, DDMC-p53 plus microwave, and DDMC-p53 plus cisplatin plus microwave energy.

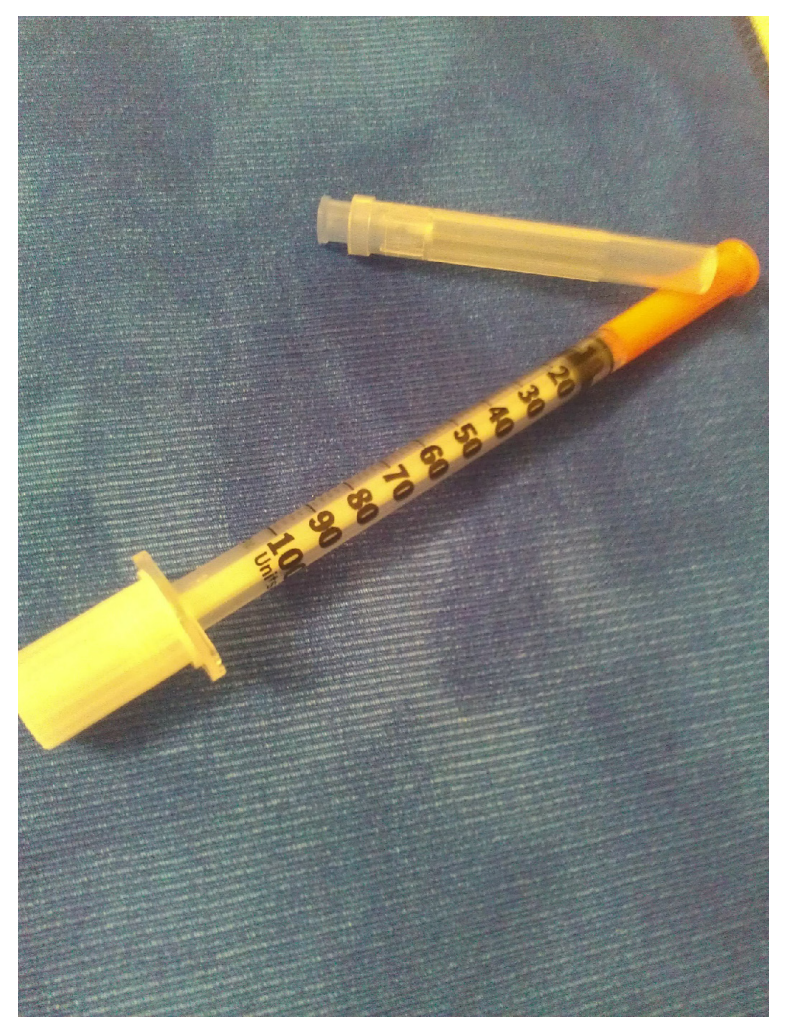

Figure I Injection used to apply Lewis lung carcinoma cells. 


\section{Gene therapy}

The non-viral vector was purchased from Ryujyu Science Corporation (Seto City, Japan) by WH-S and PZ. This vector has the following characteristics: it is a rapid and easy procedure to perform, is stable for sterilization by autoclaving at $121^{\circ} \mathrm{C}$ for 15 minutes, has broad peak performance, is amenable to high-throughput screening, shows no serum inhibition, it is a broad cell line range, and has the best results with small interfering RNA, excellent reproducibility, low toxicity in comparison with DEAE-dextran, high efficiency with use of low amounts of DNA, high DNase protection by DNase degradation, and a favorable price/value ratio.

The p53 plasmid was purchased from Addgene Laboratory (Cambridge, MA, USA) by KZ. Enhanced green fluorescent protein is expressed from this plasmid as a marker, but it is not a fusion protein. Cre causes the enhanced green fluorescent protein to be recombined out of the construct, activating expression of short hairpin RNA (pSico vector backbone, with the vector type being mammalian expression, lentiviral, RNA interference, Cre/Lox). ${ }^{47}$ The procedure used for preparation of the complex (non-viral vector, p53) has been described previously, and $0.2 \mathrm{~mL}$ was injected into each tumor at three different sites ${ }^{48,49}$ (Figures 2 and 3).

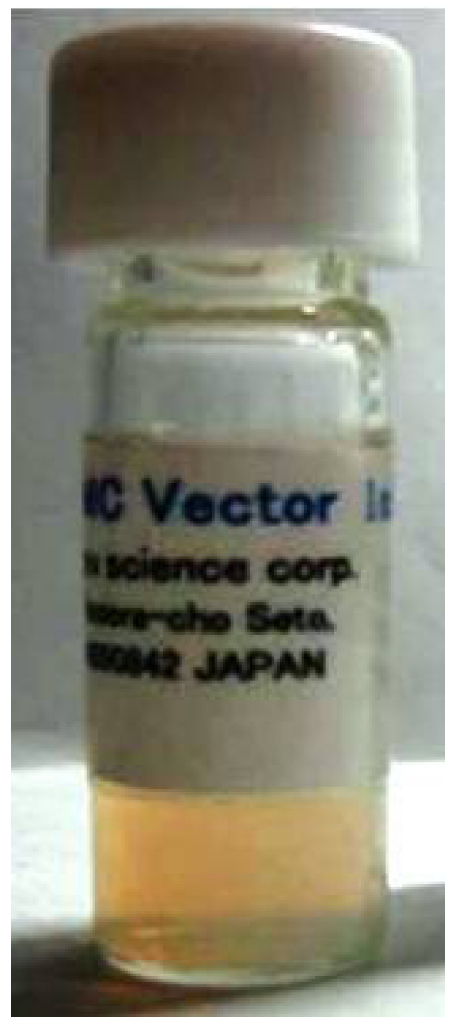

Figure 2 Vial containing the non-viral DDMC vector.

\section{Chemotherapy agent}

The non-specific cytotoxic agent cisplatin (Onco-Tain ${ }^{\mathrm{TM}}$; Hospira UK, Ltd) $100 \mathrm{mg} / 100 \mathrm{~mL}$ was obtained from our pulmonary oncology department at G Papanikolaou General Hospital, Aristotle University of Thessaloniki, Thessaloniki, Greece.

\section{Microwave ablation system}

A Valleylab ${ }^{\mathrm{TM}}$ microwave ablation generator system, manufactured for Valleylab, a division of Tyco Healthcare Group LP Boulder, (Boulder, CO, USA) was kindly provided by Joshua Stopek (Figure 4).

\section{Treatment administration}

We performed the experiment within 4 weeks of the median tumor volume reaching $100 \mathrm{~mm}^{3}$, based on our previous experience. $^{24,50}$ All mice were euthanized when week 4 arrived. We also sacrificed a mouse from each group after the first administration of therapy to obtain samples for pathology. Administration of the DDMC complex was performed with a 27-gauge needle (Figure 1), although we observed that the solution was thick and difficult to handle. All solutions/drug volume dosage that had to be injected into the tumor was administered at different sites on the tumor surface. Treatment was administered twice per week. A survival record was kept for each group. One milliliter of cisplatin was administered at each treatment session. The microwave ablation spike was able to be inserted into the center of the tumor, since the tumor was not larger than $1 \mathrm{~cm}$ in diameter in most cases. As indicated by the manufacturer (http://surgical.covidien.com/products/ablation-systems/ microwave-ablation/evident-mwa-antennas), there is no need to insert an additional spike for this tumor diameter. The application was performed using $20 \mathrm{~W}$ over 10 minutes. We used a $17 \mathrm{~cm}$ spike. Each spike was inserted only $0.5-1 \mathrm{~cm}$ into the center of the tumor. We used a reduced microwave energy of $20 \mathrm{~W}$ because the $45 \mathrm{~W}$ used in our previous experiment was very toxic. ${ }^{41} \mathrm{We}$ administered $0.5 \mathrm{~mL}$ of the DDMC-p53 complex at three different sites in the tumor.

\section{Results}

We investigated whether gene therapy prior to microwave ablation can enhance the effect of chemotherapy or microwave ablation. We observed increased toxicity in the group treated using the DDMC-p53 complex simultaneously with cisplatin and microwave ablation (median survival 6 days). Moreover, more than ten mice died immediately after administration of the experimental treatment. Moreover, increased 


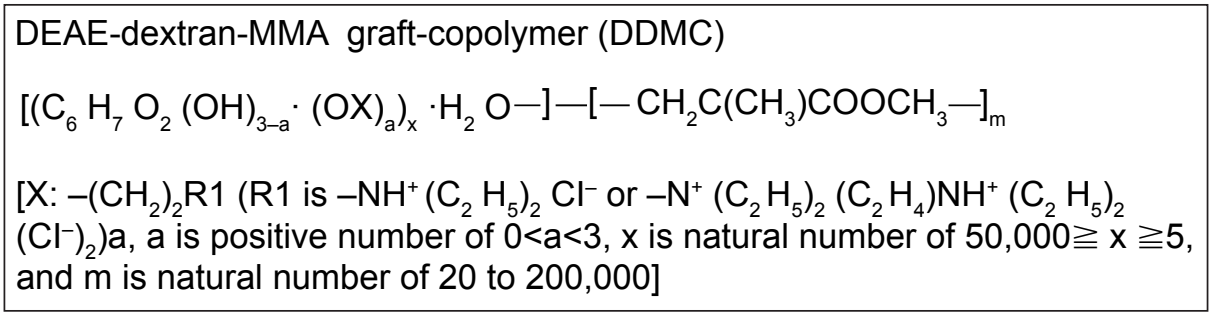

Figure 3 Molecular structure of the non-viral vector DDMC.

Abbreviation: DDMC-p53, 2-diethylaminoethyl-dextran methyl methacrylate copolymer with p53.

toxicity was observed in the DDMC-p53 plus cisplatin group, however this group survived longer (median group survival 15 days) than the previous group. The group that received DDMC-p53 and cisplatin had a median survival of 15 days. The group with cisplatin had a median survival of 16 days. The group that received microwave ablation alone had the longest survival (19 days), probably due to the low toxicity of the therapy. The control group had a median survival of 12 days. Infection developed in several cases due to repeated syringe puncture, and we suspect that the survival time could be different if the drugs were administered using a different method (Figures 5-12). The gene therapy was administered first, followed an hour later by cisplatin or microwave ablation depending on the treatment group. The volume of cisplatin was divided in three different sites of the tumor within a triangle.

\section{Discussion}

Non-specific cytotoxic agents are considered the tip of the arrow in the treatment of lung cancer. ${ }^{7,8}$ In the case of adenocarcinoma, the effects of use of epidermal growth factor

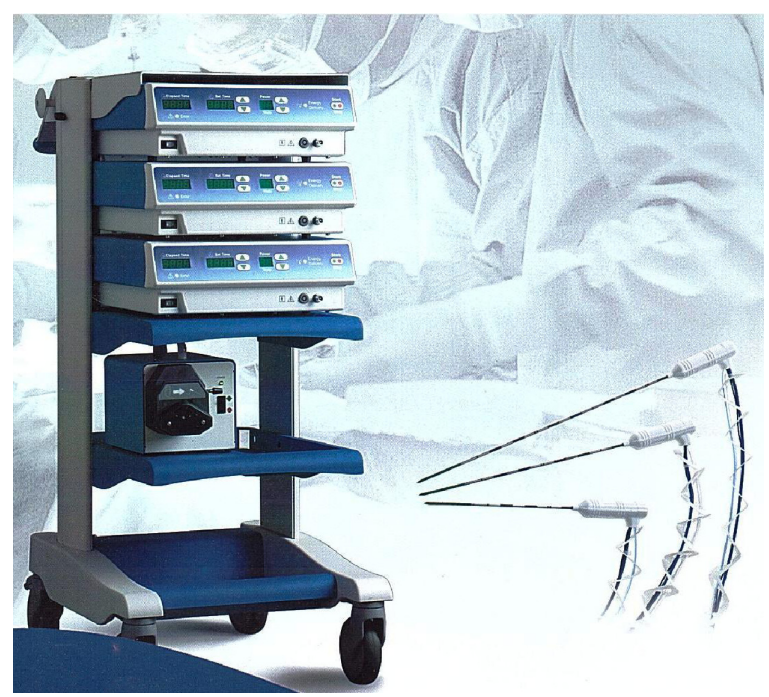

Figure 4 Microwave ablation generator manufactured by Valleylab, a division of Tyco Healthcare Group LP (Boulder, CO, USA) and kindly provided by Joshua Stopek. and anaplastic lymphoma kinase before administration of a standard chemotherapy regimen have to be investigated. ${ }^{8}$ Novel molecular pathways are also being investigated in lung cancer, with the mammalian target of rapamycin pathway being highlighted as a possible treatment target. ${ }^{51}$ Nonspecific cytotoxic agents have been investigated in the form of local treatment by needle administration into lymph nodes or direct administration into the tumor mass with fiber optic bronchoscopy or an endobronchial ultrasound system. ${ }^{11}$ Using this methodology, it was reported that there were less side effects than usually observed with intravenous administration. However, it has been observed that an abscess can be formed within the tumor mass after several administrations. Intratumoral chemotherapy has also been used for prostate cancer, glioblastoma, melanoma, breast cancer, neuroblastoma, and hepatocellular carcinoma. ${ }^{52-60}$ Several vectors have been used

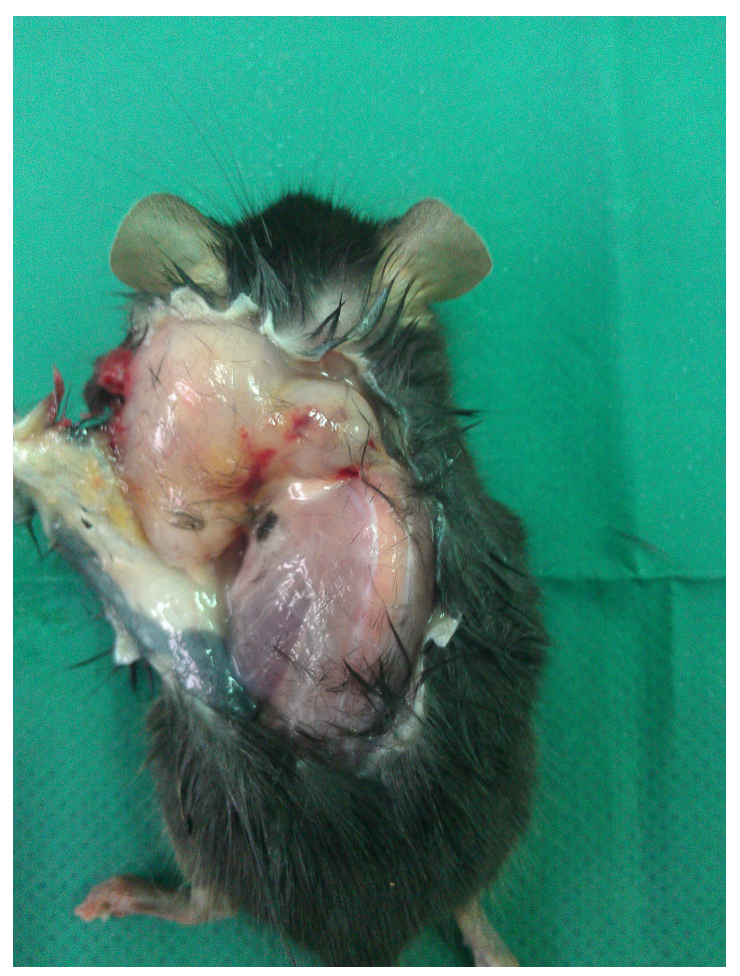

Figure 5 BALBC mouse with tumor. 


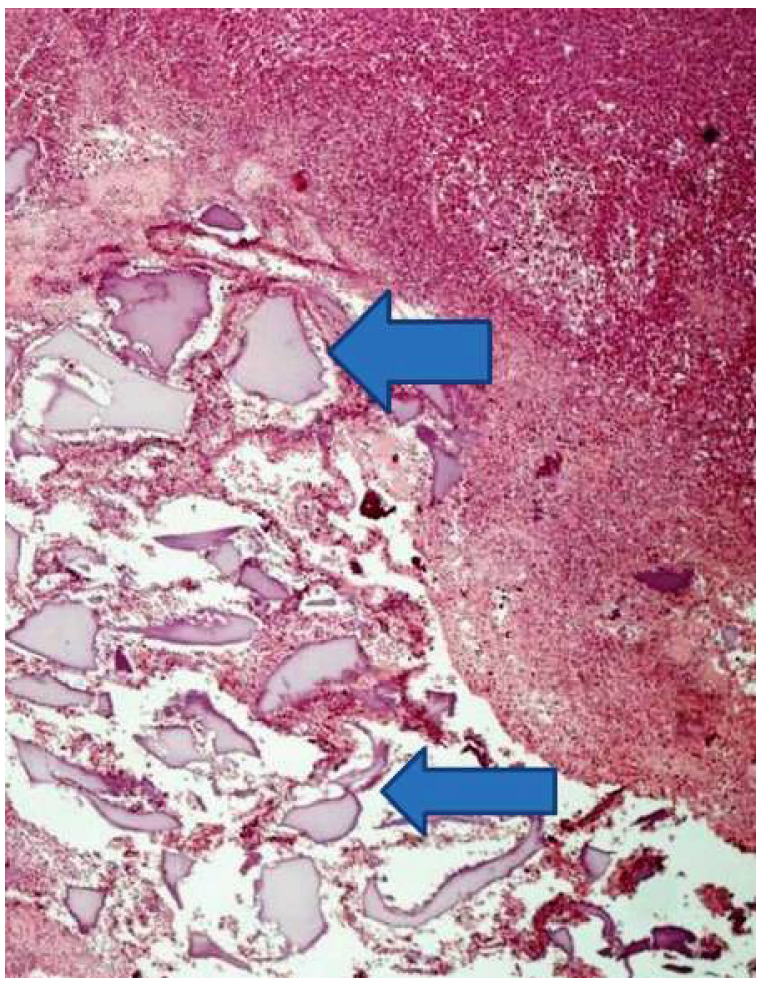

Figure 6 DDMC with $p 53$.

Notes: Blue arrows indicate the DDMC-p53 complex within the tissue. Magnification $100 \times$.

Abbreviation: DDMC, 2-diethylaminoethyl-dextran methyl methacrylate copolymer.

in studies such as these, with different intratumoral therapeutic strategies. Gene therapy is used to insert genetic material into a cell. ${ }^{10,26,29,30,61}$ There are currently two vehicles that are used for efficient gene transportation, ie, viral and non-viral vectors, and each vehicle has its advantages and disadvantages. The viral vectors tend to induce neutralizing antibodies within 3-7 days, and several non-viral vectors have a low DNA uptake ability and have been observed to be toxic to certain normal cells, such as the airway epithelium. 10,26,29,30,61

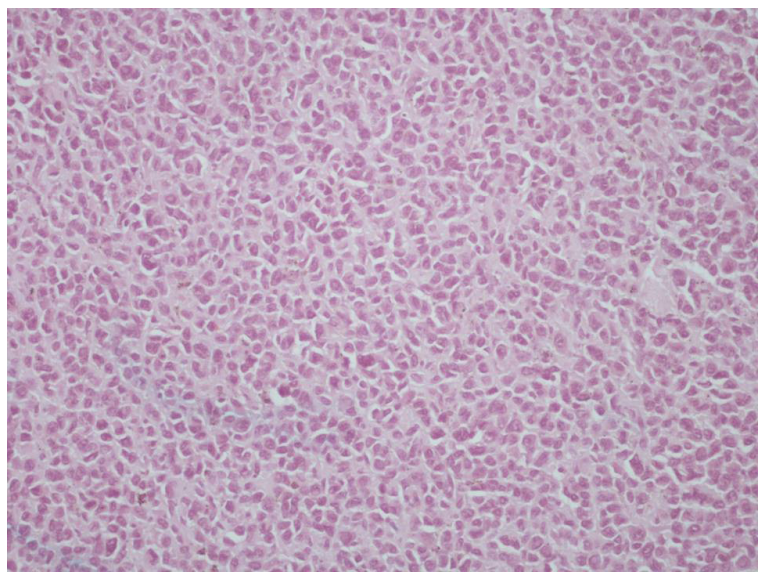

Figure 7 Control group (without therapy). Note: Magnification 100x.

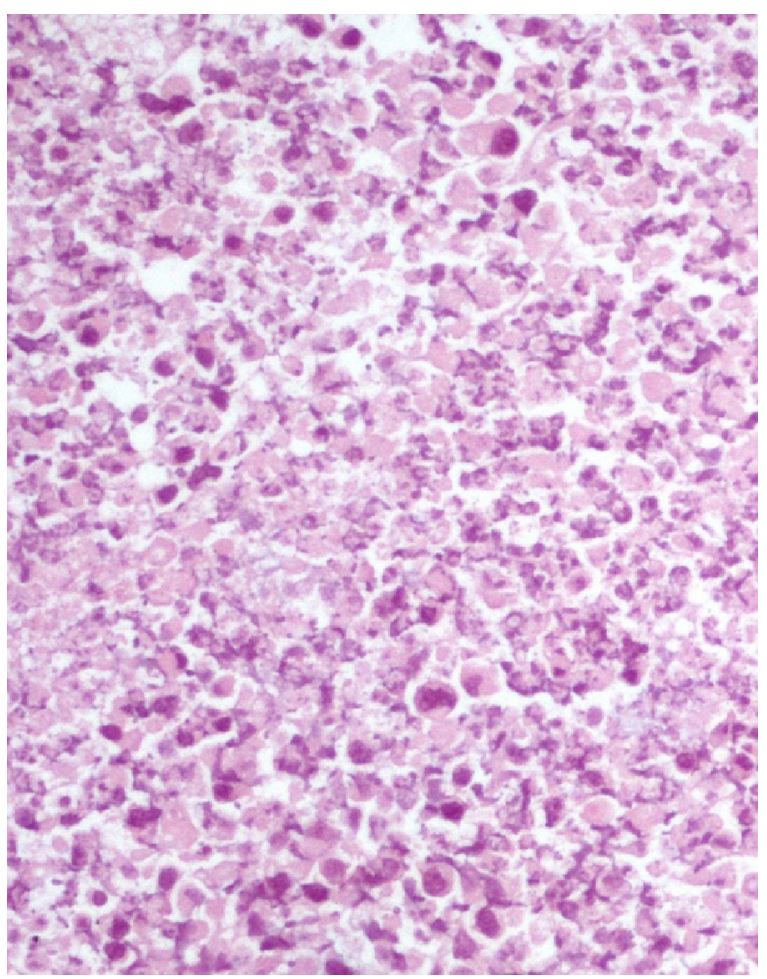

Figure 8 DDMC with $p 53$ plus microwave group.

Note: Magnification 100x.

Abbreviation: DDMC, 2-diethylaminoethyl-dextran methyl methacrylate copolymer.

There are some basic principles when we are considering a drug for intratumoral administration, in particular passive transport, which is based on the physicochemical properties of the injected compound, and active transport, which is based on the concept of antigen-antibody connection. ${ }^{33}$ Heating and cooling techniques have also been used to enhance drug diffusion. ${ }^{62,63}$ The time release effect plays a major role in this

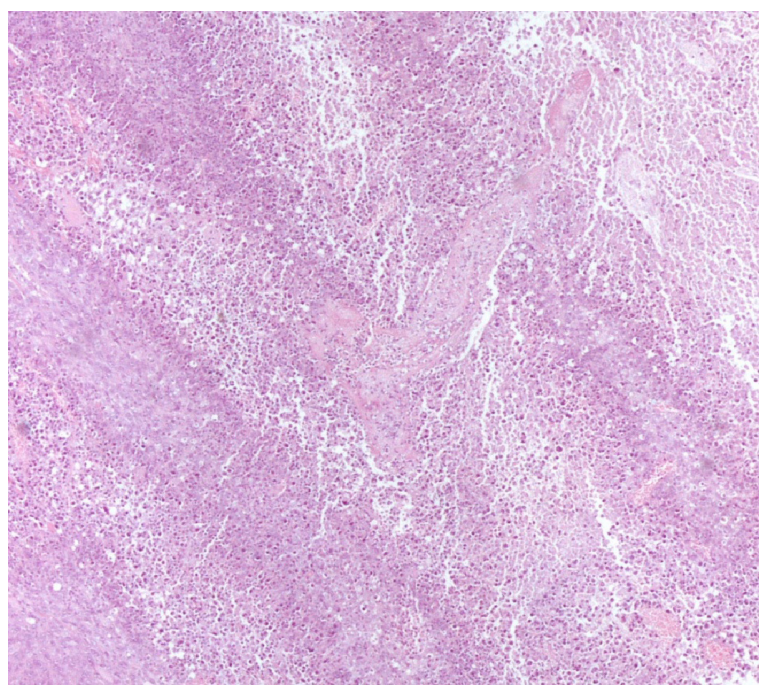

Figure 9 DDMC-p53 complex plus cisplatin.

Note: Magnification $40 x$.

Abbreviation: DDMC, 2-diethylaminoethyl-dextran methyl methacrylate copolymer. 


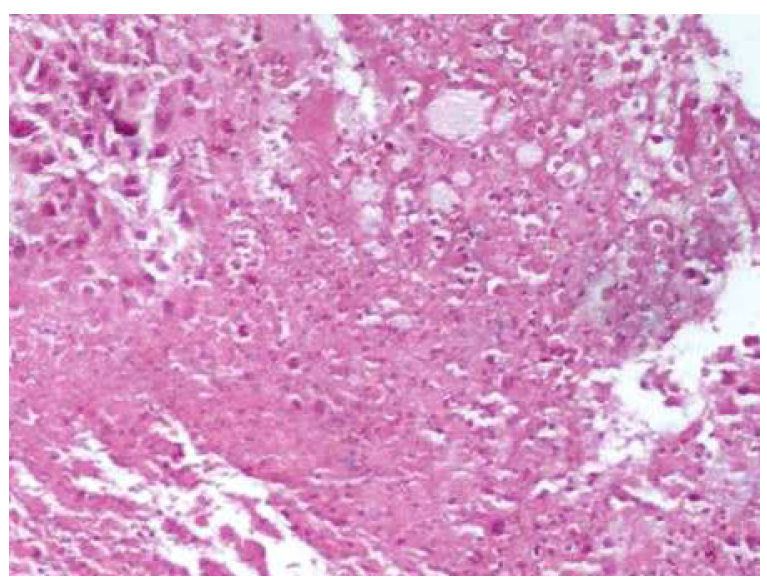

Figure 10 Cisplatin group.

Note: Magnification I00x.

type of treatment since it prolongs local deposition to the target tissue and increases apoptosis. Carriers have been investigated in order to achieve a local sustained-release effect. ${ }^{64,65}$

DDMC-p53 has been investigated previously by the authors as a possible treatment for lung cancer. ${ }^{24}$ There are

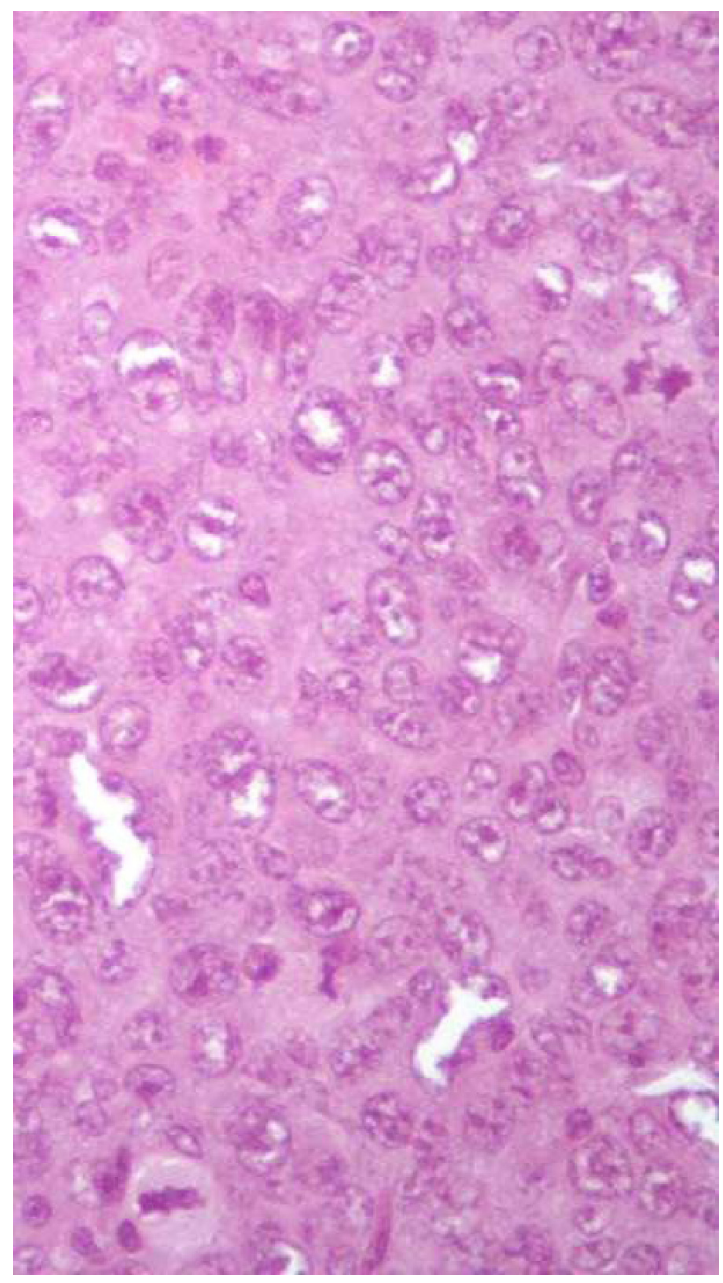

Figure II Microwave group. Note: Magnification 100x.

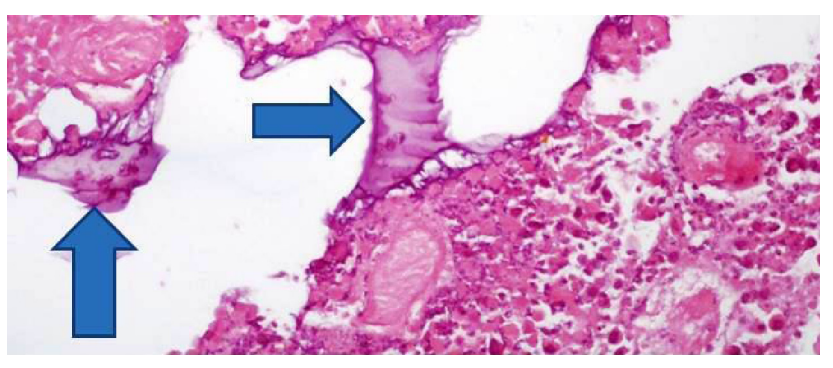

Figure 12 DDMC-p53 plus cisplatin plus microwave group.

Notes: Magnification 100x. The blue arrows indicate the DDMC-p53 complex within the tissue.

Abbreviation: DDMC, 2-diethylaminoethyl-dextran methyl methacrylate copolymer.

currently very few data regarding gene therapy in combination with microwave ablation. Until now, gene therapy has been investigated in the context of targeting vascular endothelial growth factor, epidermal growth factor, Kras, extracellular matrix factors, immunotherapy, and the tumor microenvironment. ${ }^{52,58,59,66-69}$ There is a vast literature concerning methods that enhance intratumoral gene therapy with the addition of chemotherapy, radiotherapy, thermal ablation, imatinib, sorafenib, rituximab, use of ultrasound system, and dendritic cells when comparing gene therapy alone. ${ }^{65,70-75}$ In a study by Sheng et al ${ }^{76}$ microwave ablation was used for hepatocellular carcinoma with addition of the recombinant adenovirus p53 gene and interleukin-2 intravenously. This was one of the first studies to combine microwave ablation with gene therapy. The efficiency of intratumoral treatment is dependent on local hypoxia, interstitial fluid pressure within the tumor, heterogeneous distribution due to abnormal vessel formation within the tumor, structural abnormalities within the tumor, and the extracellular matrix, which consists of collagen, tumor cells, fibroblasts, and elastin. ${ }^{38}$

Previous studies have demonstrated the efficiency of application of microwave energy with spikes as a local treatment for cancer, particularly lung cancer. ${ }^{77-79}$ This treatment method is safer for the elderly (aged $>75$ years) and for patients who are not able to undergo chemotherapy ${ }^{77}$ However, this method has a major drawback in that the thermal effect has a short range around the tip of the spike. Therefore, in many cases, more than two spikes $1 \mathrm{~cm}$ apart are inserted in the tumor in order to enhance the effect (http://surgical.covidien.com/ products/ablation-systems/microwave-ablation/evident-mwaantennas). ${ }^{79}$ Computed tomography has been used until now, but novel studies are currently investigating the use of ultrasound for correct insertion of spikes into the tumor lesion. ${ }^{80}$ The thermal effect of microwave ablation has been shown to be effective for lesions $<3 \mathrm{~cm}$, distant to vessels. Recurrence in these cases is rare.$^{81}$ The thermal effect of this therapy ( 3 minutes at least) has the ability to expand the tissue locally 
by up to $25 \%$ and then the contraction takes place. ${ }^{82}$ Novel spikes are currently being investigated. ${ }^{83}$

One of the limitations of our study is that we did not acquire a magnetic resonance imaging scan for each tumor tissue specimen immediately after administration of therapy or euthanasia. ${ }^{41}$ We concluded, based on our previous experiment, that in order to investigate the thermal effect and modification of the extracellular matrix by magnetic resonance imaging, we should euthanize and acquire the tumor tissue specimen immediately after administration. ${ }^{41}$ Moreover, local infection was an issue that we were not able to overcome completely since each solution had to be administered several times. Also, we were not able to perform our experiment in a larger animal model which we would consider more appropriate. Pigs weighing $60 \mathrm{~kg}$ should probably be used as a lung cancer model since the respiratory system of an adult pig at this weight resembles that of the human respiratory system. We were not able to take blood samples in order to measure systemic side effects due to the small animal size. Further, we were not able to monitor the mice 24 hours a day 7 days a week, so if a mouse died within a weekend or at night, we did not measure the tumor volume, since the specimen was dehydrated, and did not include these tumor or volume measurements in our results.

We conclude that local combination therapies can be used for the treatment of lung cancer treatment to improve local control with less side effects. However, several issues have to be appropriately addressed, such as, the properties of the solution injected into the tumor mass, and the dosage of each agent has to be selected according to tumor volume and density. The volume of gene therapy administered should be increased from $0.5 \mathrm{~mL}$ to $1 \mathrm{~mL}$, and other gene therapy models should be used. Again, more experiments are needed in order to identify a local therapeutic model with less drug concentration and higher therapeutic efficiency.

\section{Acknowledgments}

WH-S and PZ thank Professor Thomas Vogl for his useful insights as an expert in the field of microwave ablation and Joshua Stopek who provided the microwave ablation generator (ValleyLab ${ }^{\mathrm{TM}}$ ). Without their motivation, help, and useful insight, this project would not have been fulfilled. Lonny Yarmus, Division of Pulmonary and Critical Care Medicine, Johns Hopkins University, Baltimore, MD, USA, performed the English language editing as requested.

\section{Disclosure}

The authors report no conflicts of interest in this work.

\section{References}

1. Davis KL, Goyal RK, Able SL, Brown J, Li L, Kaye JA. Real-world treatment patterns and costs in a US Medicare population with metastatic squamous non-small cell lung cancer. Lung Cancer. November 8, 2014. [Epub ahead of print].

2. Tsiouda T, Zarogoulidis P, Petridis D, et al. A multifactoral analysis of 1452 patients for smoking sensation. An outpatient lab experience. J Cancer. 2014;5(6):433-445.

3. Zarogoulidis K, Zarogoulidis P, Darwiche K, et al. Treatment of non-small cell lung cancer (NSCLC). J Thorac Dis. 2013;5 Suppl 4: S389-S396.

4. Zarogoulidis P, Tsakiridis K, Zarogoulidis K. Lung cancer: an update on current and future diagnostic and treatment techniques. $J$ Thorac Dis. 2013;5 Suppl 4:S341.

5. Baltayiannis N, Chandrinos M, Anagnostopoulos D, et al. Lung cancer surgery: an up to date. J Thorac Dis. 2013;5 Suppl 4:S425-S439.

6. Kallianos A, Rapti A, Zarogoulidis P, et al. Therapeutic procedure in small cell lung cancer. J Thorac Dis. 2013;5 Suppl 4:S420-S424.

7. Boutsikou E, Kontakiotis T, Zarogoulidis P, et al. Docetaxel-carboplatin in combination with erlotinib and/or bevacizumab in patients with nonsmall cell lung cancer. Onco Targets Ther. 2013;6:125-134.

8. Domvri K, Zarogoulidis P, Darwiche K, et al. Molecular targeted drugs and biomarkers in NSCLC, the evolving role of individualized therapy. J Cancer. 2013;4:736-754.

9. Zarogoulidis P, Darwiche K, Krauss L, et al. Inhaled cisplatin deposition and distribution in lymph nodes in stage II lung cancer patients. Future Oncol. 2013;9(9):1307-1313.

10. Zarogoulidis P, Darwiche K, Hohenforst-Schmidt W, et al. Inhaled gene therapy in lung cancer: proof-of-concept for nano-oncology and nanobiotechnology in the management of lung cancer. Future Oncol. 2013; 9(8):1171-1194.

11. Hohenforst-Schmidt W, Zarogoulidis P, Darwiche K, et al. Intratumoral chemotherapy for lung cancer: re-challenge current targeted therapies. Drug Des Devel Ther. 2013;7:571-583.

12. Zaric B, Stojsic V, Tepavac A, et al. Adjuvant chemotherapy and radiotherapy in the treatment of non-small cell lung cancer (NSCLC). J Thorac Dis. 2013;5 Suppl 4:S371-S377.

13. Zaric B, Stojsic V, Kovacevic T, et al. Clinical characteristics, tumor, node, metastasis status, and mutation rate in domain of epidermal growth factor receptor gene in serbian patients with lung adenocarcinoma. J Thorac Oncol. 2014;9:1406-1410.

14. Boukovinas I, Tsakiridis K, Zarogoulidis P, et al. Neo-adjuvant chemotherapy in early stage non-small cell lung cancer. J Thorac Dis. 2013;5 Suppl 4:S446-S448.

15. Zarogoulidis K, Latsios D, Porpodis K, et al. New dilemmas in smallcell lung cancer TNM clinical staging. Onco Targets Ther. 2013;6: 539-547.

16. Lithoxopoulou H, Zarogoulidis K, Bostantzopoulou S, et al. Monitoring changes in quality of life in patients with lung cancer by using specialised questionnaires: implications for clinical practice. Support Care Cancer. 2014;22:2177-2183.

17. Miller PJ, Balu S, Buchner D, Walker MS, Stepanski EJ, Schwartzberg LS Willingness to pay to prevent chemotherapy induced nausea and vomiting among patients with breast, lung, or colorectal cancer. JMed Econ. 2013;16:1179-1189.

18. Grossi F, Genova C, Gaitan ND, et al. Free drugs in clinical trials and their potential cost saving impact on the National Health Service: a retrospective cost analysis in Italy. Lung Cancer. 2013;81:236-240.

19. Zarogoulidou V, Panagopoulou E, Papakosta D, et al. Estimating the direct and indirect costs of lung cancer: a prospective analysis in a Greek University Pulmonary Department. J Thorac Dis. 2015;7 Suppl 1:S12-S19.

20. Porpodis K, Karanikas M, Zarogoulidis P, et al. A case of typical pulmonary carcinoid tumor treated with bronchoscopic therapy followed by lobectomy. J Multidiscip Healthc. 2012;5:47-51.

21. Mavroudi M, Zarogoulidis P, Porpodis K, et al. Stem cells' guided gene therapy of cancer: new frontier in personalized and targeted therapy. $J$ Cancer Res Ther (Manch). 2014;2:22-33. 
22. Hohenforst-Schmidt W, Zarogoulidis P, Linsmeier B, et al. Enhancement of aerosol cisplatin chemotherapy with gene therapy expressing ABC10 protein in respiratory system. $J$ Cancer. 2014;5:344-350.

23. Zarogoulidis P, Darwiche K, Sakkas A, et al. Suicide gene therapy for cancer - current strategies. J Genet Syndr Gene Ther. 2013;4:pii 16849.

24. Baliaka A, Zarogoulidis P, Domvri K, et al. Intratumoral gene therapy versus intravenous gene therapy for distant metastasis control with 2-diethylaminoethyl-dextran methyl methacrylate copolymer non-viral vector-p53. Gene Ther. 2014;21:158-167.

25. Zarogoulidis P, Petridis D, Ritzoulis C, et al. Establishing the optimal nebulization system for paclitaxel, docetaxel, cisplatin, carboplatin and gemcitabine: back to drawing the residual cup. Int J Pharm. 2013;453: 480-487.

26. Darwiche K, Zarogoulidis P, Karamanos NK, et al. Efficacy versus safety concerns for aerosol chemotherapy in non-small-cell lung cancer: a future dilemma for micro-oncology. Future Oncol. 2013;9:505-525.

27. Zarogoulidis P, Chatzaki E, Porpodis K, et al. Inhaled chemotherapy in lung cancer: future concept of nanomedicine. Int J Nanomedicine. 2012;7:1551-1572.

28. Zarogoulidis P, Eleftheriadou E, Sapardanis I, et al. Feasibility and effectiveness of inhaled carboplatin in NSCLC patients. Invest New Drugs. 2012;30:1628-1640.

29. Zarogoulidis P, Giraleli C, Karamanos NK. Inhaled chemotherapy in lung cancer: safety concerns of nanocomplexes delivered. Ther Deliv. 2012;3:1021-1023.

30. Zarogoulidis P, Kontakiotis T, Zarogoulidis K. Inhaled gene therapy in lung cancer: "as for the future, our task is not to foresee it, but to enable it". Ther Deliv. 2012;3:919-921.

31. Zarogoulidis P, Darwiche K, Yarmus L, et al. Defense mechanisms of the respiratory system and aerosol production systems. Med Chem. 2014; 10:123-136.

32. Zarogoulidis P, Papanas N, Kouliatsis G, Spyratos D, Zarogoulidis K, Maltezos E. Inhaled insulin: too soon to be forgotten? J Aerosol Med Pulm Drug Deliv. 2011;24:213-223.

33. Bae YH. Interview with Dr You Han Bae: ligand-mediated versus 'passive' targeting approaches in nanoparticle oncology research. Ther Deliv. 2012;3:933-936.

34. Palussiere J, Lagarde P, Auperin A, Deschamps F, Chomy F, de Baere T. Percutaneous lung thermal ablation of non-surgical clinical N0 nonsmall cell lung cancer: results of eight years' experience in 87 patients from two centers. Cardiovasc Intervent Radiol. 2015;38:160-166.

35. Andreetti C, Maurizi G, Cassiano F, Rendina EA. Resolution of a life-threatening complication after lung radiofrequency ablation. Eur J Cardiothorac Surg. 2014;46:e56-e58.

36. Solazzo SA, Ahmed M, Schor-Bardach R, et al. Liposomal doxorubicin increases radiofrequency ablation-induced tumor destruction by increasing cellular oxidative and nitrative stress and accelerating apoptotic pathways. Radiology. 2010;255:62-74.

37. Sim H, Bibee K, Wickline S, Sept D. Pharmacokinetic modeling of tumor bioluminescence implicates efflux, and not influx, as the bigger hurdle in cancer drug therapy. Cancer Res. 2011;71:686-692.

38. Stylianopoulos T. EPR-effect: utilizing size-dependent nanoparticle delivery to solid tumors. Ther Deliv. 2013;4:421-423.

39. Fang J, Qin H, Nakamura H, Tsukigawa K, Shin T, Maeda H. Carbon monoxide, generated by heme oxygenase-1, mediates the enhanced permeability and retention effect in solid tumors. Cancer Sci. 2012;103:535-541.

40. Zhao W, Zhuang S, Qi XR. Comparative study of the in vitro and in vivo characteristics of cationic and neutral liposomes. Int J Nanomedicine. 2011;6:3087-3098.

41. Hohenforst-Schmidt W, Zarogoulidis P, Stopek J, et al. Enhancement of intratumoral chemotherapy with cisplatin with or without microwave ablation and lipiodol. Future concept for local treatment in lung cancer. $J$ Cancer. 2015;6:218-226.

42. Zarogoulidis P, Hohenforst-Schmidt W, Darwiche K, et al. 2diethylaminoethyl-dextran methyl methacrylate copolymer nonviral vector: still a long way toward the safety of aerosol gene therapy. Gene Ther. 2013;20:1022-1028.
43. Sakkas A, Zarogoulidis P, Domvri K, et al. Safety and efficacy of suicide gene therapy with adenosine deaminase 5-fluorocytosine silmutaneously in in vitro cultures of melanoma and retinal cell lines. J Cancer. 2014;5: 368-381.

44. Domvri K, Zarogoulidis P, Theodoropoulos F, Huang H, Zarogoulidis K. Establishment of a malignant pleural effusion mouse model: pathogenesis pathways. Transl Lung Cancer Res. 2012;1:163-166.

45. Bertram JS, Janik P. Establishment of a cloned line of Lewis lung carcinoma cells adapted to cell culture. Cancer Lett. 1980;11: 63-73.

46. Zarogoulidis P, Chatzaki E, Hohenforst-Schmidt W, et al. Management of malignant pleural effusion by suicide gene therapy in advanced stage lung cancer: a case series and literature review. Cancer Gene Ther. 2012;19:593-600.

47. Ventura A, Meissner A, Dillon CP, et al. Cre-lox-regulated conditional RNA interference from transgenes. Proc Natl Acad Sci U S A. 2004;101: 10380-10385.

48. Eshita Y, Higashihara J, Onishi M, et al. Mechanism of the introduction of exogenous genes into cultured cells using DEAE-dextran-MMA graft copolymer as a non-viral gene carrier. II. Its thixotropy property. J Nanomed Nanotechnol. 2011;2:104.

49. Onishi Y, Eshita Y, Murashita A, Mizuno M, Yoshida J. Synthesis and characterization of 2-diethyl-aminoethyl-dextran-methyl methacrylate graft copolymer for nonviral gene delivery vector. J Appl Polym Sci. 2005;98:9-14.

50. Veenstra JJ, Gibson HM, Freytag S, Littrup PJ, Wei WZ. In situ immunization via non-surgical ablation to prevent local and distant tumor recurrence. Oncoimmunology. 2015;4(3):e989762.

51. Zarogoulidis P, Lampaki S, Turner JF, et al. mTOR pathway: a current, up-to-date mini-review. Oncol Lett. 2014;8:2367-2370.

52. Leifler KS, Svensson S, Abrahamsson A, et al. Inflammation induced by MMP-9 enhances tumor regression of experimental breast cancer. J Immunol. 2013;190:4420-4430.

53. Peng YF, Shi YH, Ding ZB, et al. Alpha-fetoprotein promoter-driven Cre/LoxP-switched RNA interference for hepatocellular carcinoma tissue-specific target therapy. PLoS One. 2013;8:e53072.

54. Chen Q, Cheng P, Song N, et al. Antitumor activity of placenta-derived mesenchymal stem cells producing pigment epithelium-derived factor in a mouse melanoma model. Oncol Lett. 2012;4:413-418.

55. Li H, Nakashima H, Decklever TD, Nace RA, Russell SJ. HSV-NIS, an oncolytic herpes simplex virus type 1 encoding human sodium iodide symporter for preclinical prostate cancer radiovirotherapy. Cancer Gene Ther. 2013;20:478-485.

56. Hallett MA, Teng B, Hasegawa H, Schwab LP, Seagroves TN, Pourmotabbed T. Anti-matrix metalloproteinase-9 DNAzyme decreases tumor growth in the MMTV-PyMT mouse model of breast cancer. Breast Cancer Res. 2013;15:R12.

57. Puntel M, A KMG, Farrokhi C, et al. Safety profile, efficacy, and biodistribution of a bicistronic high-capacity adenovirus vector encoding a combined immunostimulation and cytotoxic gene therapy as a prelude to a phase I clinical trial for glioblastoma. Toxicol Appl Pharmacol. 2013;268:318-330.

58. Huang S, Shao K, Kuang Y, et al. Tumor targeting and microenvironmentresponsive nanoparticles for gene delivery. Biomaterials. 2013; 34:5294-5302.

59. Ramachandran M, Yu D, Wanders A, Essand M, Eriksson F. An infection-enhanced oncolytic adenovirus secreting H. pylori neutrophilactivating protein with therapeutic effects on neuroendocrine tumors. Mol Ther. 2013;21:2008-2018.

60. Kasai K, Nakashima H, Liu F, et al. Toxicology and biodistribution studies for MGH2.1, an oncolytic virus that expresses two prodrugactivating genes, in combination with prodrugs. Mol Ther Nucleic Acids. 2013;2:e113.

61. Chirmule N, Hughes JV, Gao GP, Raper SE, Wilson JM. Role of E4 in eliciting CD4 T-cell and B-cell responses to adenovirus vectors delivered to murine and nonhuman primate lungs. $J$ Virol. 1998;72: $6138-6145$. 
62. Yang W, Ahmed M, Elian M, et al. Do liposomal apoptotic enhancers increase tumor coagulation and end-point survival in percutaneous radiofrequency ablation of tumors in a rat tumor model? Radiology. 2010; 257:685-696.

63. Le Pivert PJ, Morrison DR, Haddad RS, et al. Percutaneous tumor ablation: microencapsulated echo-guided interstitial chemotherapy combined with cryosurgery increases necrosis in prostate cancer. Technol Cancer Res Treat. 2009;8:207-216.

64. Lin X, Gao R, Zhang Y, et al. Lipid nanoparticles for chemotherapeutic applications: strategies to improve anticancer efficacy. Expert Opin Drug Deliv. 2012;9:767-781.

65. Xie H, Goins B, Bao A, Wang ZJ, Phillips WT. Effect of intratumoral administration on biodistribution of $64 \mathrm{Cu}-$ labeled nanoshells. Int $J$ Nanomedicine. 2012;7:2227-2238.

66. Zou Y, Tornos C, Qiu X, Lia M, Perez-Soler R. p53 aerosol formulation with low toxicity and high efficiency for early lung cancer treatment. Clin Cancer Res. 2007;13:4900-4908.

67. Frederiksen KS, Abrahamsen N, Cristiano RJ, Damstrup L, Poulsen HS. Gene delivery by an epidermal growth factor/DNA polyplex to small cell lung cancer cell lines expressing low levels of epidermal growth factor receptor. Cancer Gene Ther. 2000;7:262-268.

68. Kim HW, Park IK, Cho CS, et al. Aerosol delivery of glucosylated polyethylenimine/phosphatase and tensin homologue deleted on chromosome 10 complex suppresses Akt downstream pathways in the lung of K-ras null mice. Cancer Res. 2004;64:7971-7976.

69. Gautam A, Densmore CL, Melton S, Golunski E, Waldrep JC. Aerosol delivery of PEI-p53 complexes inhibits B16-F10 lung metastases through regulation of angiogenesis. Cancer Gene Ther. 2002;9: 28-36.

70. Horev-Drori G, Cooks T, Bittan H, et al. Local control of experimental malignant pancreatic tumors by treatment with a combination of chemotherapy and intratumoral 224radium-loaded wires releasing alpha-emitting atoms. Transl Res. 2012;159:32-41.

71. Ahmed M, Moussa M, Goldberg SN. Synergy in cancer treatment between liposomal chemotherapeutics and thermal ablation. Chem Phys Lipids. 2012;165:424-437.
72. Son CH, Shin DY, Kim SD, et al. Improvement of antitumor effect of intratumoral injection of immature dendritic cells into irradiated tumor by cyclophosphamide in mouse colon cancer model. $J$ Immunother. 2012;35:607-614.

73. Raut CP, Boucher Y, Duda DG, et al. Effects of sorafenib on intratumoral interstitial fluid pressure and circulating biomarkers in patients with refractory sarcomas (NCI protocol 6948). PLoS One. 2012; 7:e26331.

74. Betting DJ, Hurvitz SA, Steward KK, et al. Combination of cyclophosphamide, rituximab, and intratumoral $\mathrm{CpG}$ oligodeoxynucleotide successfully eradicates established B cell lymphoma. J Immunother. 2012;35:534-543.

75. Lai CY, Fite BZ, Ferrara KW. Ultrasonic enhancement of drug penetration in solid tumors. Front Oncol. 2013;3:204.

76. Sheng S, Zheng J, Cui S, Cui X, Qian Z. Complete remission of multiple lung metastases after ablation of hepatocellular carcinoma by transarterial infusion with the p53 gene. Anticancer Drugs. 2015;26:227-231.

77. Acksteiner C, Steinke K. Percutaneous microwave ablation for earlystage non-small cell lung cancer (NSCLC) in the elderly: a promising outlook. J Med Imaging Radiat Oncol. 2015;59:82-90.

78. Schneider T. [Thermal ablation of malignant lung tumours]. Zentralbl Chir. 2015;140:104-108. German.

79. Winokur RS, Du JY, Pua BB, et al. Characterization of in vivo ablation zones following percutaneous microwave ablation of the liver with two commercially available devices: are manufacturer published reference values useful? J Vasc Interv Radiol. 2014;25:1939-1946.e1.

80. Wu W, Xue Y, Wang D, Xue J, Zhai W, Liang P. A simulator for percutaneous hepatic microwave thermal ablation under ultrasound guidance. Int J Hyperthermia. 2014:1-9.

81. Leung U, Kuk D, D’Angelica MI, et al. Long-term outcomes following microwave ablation for liver malignancies. Br J Surg. 2015;102:85-91.

82. Farina L, Weiss N, Nissenbaum Y, et al. Characterisation of tissue shrinkage during microwave thermal ablation. Int $J$ Hyperthermia. 2014:1-10.

83. Ito K, Saito K. Development of microwave antennas for thermal therapy. Curr Pharm Des. 2011;17:2360-2366.
OncoTargets and Therapy

\section{Publish your work in this journal}

OncoTargets and Therapy is an international, peer-reviewed, open access journal focusing on the pathological basis of all cancers, potential targets for therapy and treatment protocols employed to improve the management of cancer patients. The journal also focuses on the impact of management programs and new therapeutic agents and protocols on

\section{Dovepress}

patient perspectives such as quality of life, adherence and satisfaction. The manuscript management system is completely online and includes a very quick and fair peer-review system, which is all easy to use. Visit http://www.dovepress.com/testimonials.php to read real quotes from published authors. 